\title{
OBSERVATIONS ON AMOUNT AND DISTRIBUTION OF PRENATAL MORTALITY IN A STRAIN OF ALBINO RATS
}

\author{
M. J. K. HARPER \\ Imperial Chemical Industries Limited, Pharmaceuticals Division, \\ Research Department, Alderley Park, Macclesfield, Cheshire
}

(Received 14th May 1963)

Summary. The amount and distribution of prenatal loss has been studied during the first pregnancy in albino rats of the random-bred, specific-pathogen-free colony maintained at Alderley Park.

Out of a total of 196 virgin female rats mated and found to have spermatozoa in the vaginal smear on the following day (Day 1 of pregnancy), fourteen $(7 \cdot 1 \%$ ) failed to become pregnant. In 145 rats which became pregnant, the mean number of eggs shed was $12 \cdot 2 \pm 0 \cdot 19$ and the mean number that implanted was $10 \cdot 9 \pm 0 \cdot 19$. In eighty rats in which pregnancy was allowed to continue to the 18th to 20th day, the mean number of viable foetuses found at autopsy was $10 \cdot 1 \pm 0 \cdot 25$. In various experimental groups, pre-implantation loss ranged from $9.8 \%$ to $13.9 \%$ of the eggs ovulated, the mean being $11.1 \%$. Post-implantation loss amounted to only $7.7 \%$ of the eggs ovulated, giving a total prenatal loss of $18.8 \%$. It was found that the number of eggs ovulated was significantly related to body weight on the day of ovulation.

Out of 145 rats which became pregnant, seventy-nine (55\%) showed some loss of eggs before implantation; $191(10.8 \%)$ of the eggs were lost. Fifty-three per cent of this loss was found to be due to fertilization failure, and $43 \%$ was due to failure to develop into blastocysts. There was no correlation between the number of eggs ovulated and the number failing to develop into blastocysts, but there was a significant correlation between the number of eggs ovulated and the percentage lost before implantation. This effect, however, was confined to the individual uterine horn; the presence of large numbers of eggs in one horn did not influence the loss of eggs in the other.

In thirty-eight $(55 \%)$ out of sixty-nine pregnancies some loss of embryos occurred after implantation and sixty-six (8.7\%) embryos were lost. In no pregnancy in which implantation occurred were all the embryos lost. The number of eggs implanting in the uterus did not influence the percentage of embryos lost.

The mean diameter of implantation sites which survived to the end of pregnancy increased from $2 \cdot 41 \pm 0 \cdot 022 \mathrm{~mm}$ on Day 7 to $4 \cdot 37 \pm 0 \cdot 043$ 
$\mathrm{mm}$ on Day 11 and $10 \cdot 26 \pm 0.044 \mathrm{~mm}$ on Day 16. From examination of the remnants of implantation sites found in the uterus at autopsy an estimate could be made of the stages at which embryos died. Of the sixty-six lost after implantation, 73\% died before Day 11, 20\% between Days 11 and 13 and only $8 \%$ after Day 13 . There was an indication, not reaching the level of statistical significance, that uterine crowding may have affected the amount of loss in the middle period, but it had no effect on loss in the early period.

\section{INTRODUCTION}

In the brown rat Rattus norvegicus, the mean litter size has been reported to be as low as $5 \cdot 8$ (Feldman, 1926) and as high as 10.3 (Miller, 1911). Perry (1945) has shown that the individual number of ovulations in the wild brown rat ranges from three to eighteen. The following figures for mean litter size in the laboratory rat have been recorded: 4.5 (Slonaker \& Card, 1918), 5.5 (Hain, 1932), 5.97 to 6.26 (Hanson \& Sholes, 1924), 6.9 (Long \& Evans, 1922), 7.0 (King \& Stotsenburg, 1915), 8.6 (Tyler \& Chapman, 1948) and 8.9 (Bouricius, 1948).

Prenatal mortality also varies widely. Perry (1945) found that in the wild rat between 5 and $14 \%$ of the eggs were lost between ovulation and Day 8 of pregnancy, and $12 \%$ of the embryos were lost between Day 8 and the end of pregnancy. Total prenatal loss amounted to $20.5 \%$ of the eggs ovulated. Evans \& Bishop (1923) recorded that pre-implantation mortality amounted to $30.5 \%$ and post-implantation mortality to $6.3 \%$. Frazer (1955) claimed that different factors influenced both total and partial loss of litters both before and after Day 9 of pregnancy. One of the factors influencing all these different types and stages of loss was found to be an abnormal number of implantations.

Since most estimates of prenatal mortality in laboratory rats have been based on strains of only moderate inherent fertility, it seemed desirable to carry out a complete examination of the amount and distribution of prenatal mortality in a strain of rats of high fertility.

\section{MATERIALS AND METHODS}

The 196 rats upon which the following observations were made were obtained from the random-bred colony of specific-pathogen-free albinos (of Wistar origin) maintained at Alderley Park. They were virgin females weighing between 132 and $248 \mathrm{~g}$, and were allowed free access to water and Oakes' $\frac{5}{8}$ in. rat cubes. They were housed, six females to a cage, in cages suspended from movable racks. The ambient temperature of the animal room ranged from 20 to $25^{\circ} \mathrm{C}$.

Vaginal smears were taken daily, and those rats with a pro-oestrous smear (composed of cornified and non-cornified epithelial cells) were mated with fertile males the same evening, two females being placed with three males. The following morning smears were again taken, and only those rats showing a fully cornified smear with spermatozoa present were included in this study. This day was designated Day 1 of pregnancy. During the period (October 
1961 to May 1962) when these experiments were performed, a total of 57,054 foetuses was produced from 5629 litters born in the colony, and the average litter size was $10 \cdot 1$.

After mating the 196 rats were divided into three experimental groupings, which are summarized in Table 1.

TABLE 1

EXPERIMENTAL DESIGN

\begin{tabular}{|c|c|c|c|c|c|}
\hline \multirow[b]{2}{*}{ Group } & \multirow[b]{2}{*}{ Total } & \multicolumn{3}{|c|}{ No. rats } & \multirow[b]{2}{*}{ Treatment } \\
\hline & & $\underset{\text { pregnant }}{\text { Not }}$ & Excluded & $\begin{array}{c}\text { Included in } \\
\text { prenatal } \\
\text { mortality } \\
\text { estimates }\end{array}$ & \\
\hline 1 & 24 & 2 & 0 & 22 & $\begin{array}{l}\text { Killed on Day } 5 \text {. Eggs removed from } \\
\text { uteri and classified. Corpora lutea } \\
\text { counted. }\end{array}$ \\
\hline 2 & 84 & 8 & 0 & $76^{*}$ & $\begin{array}{l}\text { Killed on Day } 8 \text {. Implantation sites } \\
\text { and corpora lutea counted. }\end{array}$ \\
\hline 3 & 88 & 4 & 4 & $80^{*}$ & $\begin{array}{l}\text { Laparotomies performed on } 11 \text { rats on } \\
\text { Days } 5 \text { and } 6 \text {. Killed on Days } 18 \text { to } \\
20 \text {, corpora lutea counted and ovaries } \\
\text { weighed, foetuses and placentae } \\
\text { counted and weighed and foetuses } \\
\text { measured. } \\
\text { Laporatomies performed on } 69 * \text { rats } \\
\text { on Days } 7 \text { to } 16 \text { and implantation } \\
\text { sites counted and measured. Killed } \\
\text { on Days } 18 \text { to } 20 \text {, corpora lutea } \\
\text { counted and ovaries weighed, foetuses } \\
\text { and placentae counted and weighed, } \\
\text { and foetuses measured. }\end{array}$ \\
\hline Total & 196 & 14 & 4 & 178 & \\
\hline
\end{tabular}

* Where 156 rats are referred to, this figure includes the seventy-six rats in Group 3 and the eighty rats in Group 4, but where 145 rats are referred to only sixty-nine of the Group 3 animals are included.

Four rats in Group 3 were found to have no implantation sites in the uterus at laparotomy after Day 7 and were therefore excluded from this group. They were considered separately, with the non-pregnant rats from Group 2. Four other rats were excluded from Group 3 because of either death at laparotomy (two rats) or regression of most of the foetuses after laparotomy (two rats). In these latter two animals, it was considered that the laparotomy procedures had caused the foetuses to regress. No swellings were visible until Day 7. Two groups of rats were examined on both Day $10(10 a+10 b)$ and on Day 11 $(11 a+11 b)$. In Groups $10 b$ and $11 b$, the numbers of implantation sites were counted, but the swellings were not measured. The four groups that were examined on Days 5, 6, 10b and $11 \mathrm{~b}$ acted as sham-operated controls.

The amount of pre-implantation and post-implantation loss was assessed as follows:

C 
(1) Pre-implantation loss $(\%)=$

$\frac{\text { (Number of corpora lutea }- \text { Number of implantation sites) }}{\text { Number of corpora lutea }} \times 100$

(2) Post-implantation loss ( $\%)=$

$$
\frac{\text { (Number of implantation sites -Number of viable foetuses) }}{\text { Number of corpora lutea }} \times 100
$$

The deaths of embryos after implantation were classified, according to the remnants left in the uterus, into early, middle or late deaths following the scheme suggested by McLaren \& Michie (1959) for the mouse. In the present study early deaths were considered to have occurred before Day 11, middle deaths between Days 11 and 13, and late deaths after Day 13 of pregnancy.

\section{RESULTS}

\section{NUMBER OF CORPORA LUTEA}

Table 2 shows the mean numbers of corpora lutea, eggs recovered and implantation sites counted in rats killed on Days 5, 8 and 18 to 20 of pregnancy. The mean number of corpora lutea observed on Day 5 is significantly different from the mean numbers recorded for Day 8 and Days 18 to 20. There is, however, no significant difference between these two latter figures.

\section{TABLE 2}

MEAN NUMBERS OF GORPORA LUTEA, EGGS RECOVERED, AND IMPLANTATION SITES IN THE THREE EXPERIMENTAL GROUPS

\begin{tabular}{c|c|c|c|c}
\hline $\begin{array}{c}\text { Day of pregnancy } \\
\text { killed }\end{array}$ & $\begin{array}{c}\text { No. } \\
\text { rats }\end{array}$ & $\begin{array}{c}\text { No. corpora lutea } \\
\text { (mean } \pm \text { S.E.) }\end{array}$ & $\begin{array}{c}\text { No. eggs recovered } \\
\text { (mean } \pm \text { S.E.) }\end{array}$ & $\begin{array}{c}\text { No. implantation sites } \\
\text { (mean } \pm \text { S.E.) }\end{array}$ \\
\hline 5 & 24 & $11 \cdot 0 \pm 0.31$ & $8.5 \pm 0.48$ & - \\
8 & 76 & $12 \cdot 1 \pm 0.24$ & - & $10.9 \pm 0.25$ \\
18 to 20 & 80 & $12 \cdot 5 \pm 0.22$ & - & $* 10.9 \pm 0.25$ \\
\hline
\end{tabular}

* Mean value calculated from data for only sixty-nine rats. Eleven rats were laparotomized on Days 5 and 6 of pregnancy, so that in them the numbers of implantation sites could not be counted.

These data might be taken to indicate that the number of corpora lutea increased during pregnancy, and that therefore corpora lutea counts at the end of pregnancy tend to overestimate the number of eggs ovulated. However, the rats killed on Day 5, in which the low mean number of corpora lutea was counted, were not weighed, and it is possible that their mean weight was less than that of the other groups. Since the effect of body weight on the numbers of eggs shed will be shown below to be highly significant, this would seem to be a more likely explanation for the low mean number of corpora lutea counted in these rats. If an increase in the number of corpora lutea during pregnancy due to luteinization of unruptured follicles does occur, it would seem unlikely that the whole of this increase occurs between Days 5 and 8, and that there is no further increase after this time. 
Since there is significant heterogeneity between the results from Group 1 and the other two groups, only the individual numbers of ovulations for the 156 rats in Groups 2 and 3 have been pooled. A frequency distribution for the different

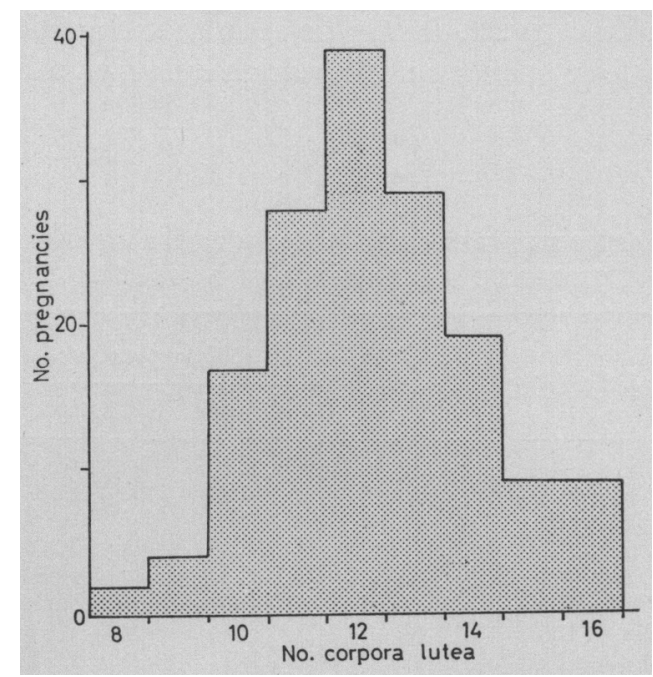

Text-FIG. 1. Distribution of the numbers of corpora lutea in 156 pregnancies.

numbers of corpora lutea observed is presented in Text-fig. 1. The lowest number of ovulations observed was eight and the highest sixteen. Thirty-nine $(25 \%)$ of the 156 rats ovulated twelve eggs.

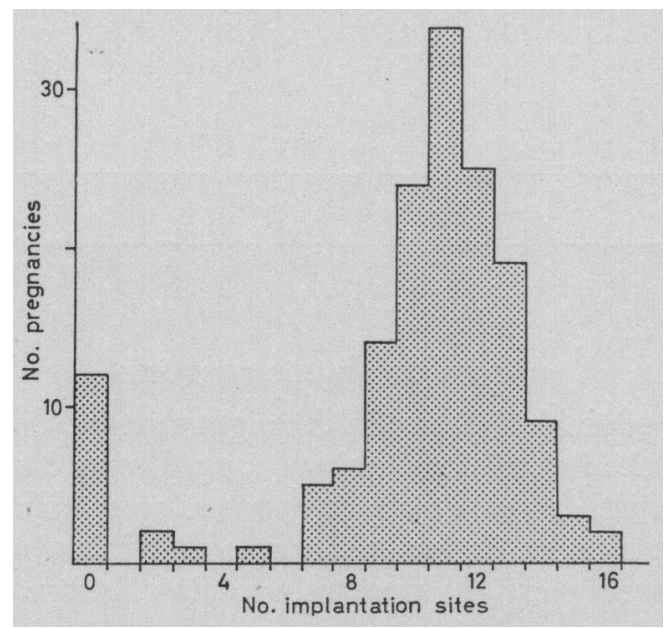

TEXT-FIG. 2. Distribution of the numbers of implantation sites in 157 pregnancies.

NUMBER OF IMPLANTATION SITES

As shown in Table 2 the mean number of implantation sites in the seventy-six (Group 2) rats that were pregnant on Day 8 and in those sixty-nine (Group 3) 
rats that were pregnant at laparotomy between Days 7 and 16 was $10 \cdot 9 \pm 0 \cdot 25$ (range 2 to 15). The individual results for both groups were therefore pooled. The frequency distribution of the numbers of implantation sites in these 145 pregnancies is shown in Text-fig. 2. The twelve rats in which no eggs implanted are also included in Text-fig. 2. It can be seen that this distribution is slightly skewed, owing to the four pregnancies in which only two to five eggs implanted.

TABLE 3

RELATIONSHIP BETWEEN BODY WEIGHT AT OVULATION AND THE NUMBER OF EGGS SHED

\begin{tabular}{|c|c|c|c|}
\hline \multirow{2}{*}{ Body wt. (g) } & \multirow{2}{*}{ No. rats } & \multicolumn{2}{|c|}{ No. corpora lutea } \\
\hline & & Total & Mean \\
\hline $\begin{array}{l}131 \text { to } 135 \\
156 \text { to } 160 \\
161 \text { to } 165 \\
166 \text { to } 170 \\
171 \text { to } 175 \\
176 \text { to } 180 \\
181 \text { to } 185 \\
186 \text { to } 190 \\
191 \text { to } 195 \\
196 \text { to } 200 \\
201 \text { to } 205 \\
206 \text { to } 210 \\
211 \text { to } 215 \\
216 \text { to } 220 \\
221 \text { to } 225 \\
226 \text { to } 230 \\
231 \text { to } 235 \\
236 \text { to } 240 \\
241 \text { to } 245 \\
246 \text { to } 250 \\
251 \text { to } 255 \\
256 \text { to } 260 \\
261 \text { to } 265\end{array}$ & $\begin{array}{r}1 \\
2 \\
2 \\
1 \\
1 \\
2 \\
6 \\
11 \\
5 \\
13 \\
16 \\
29 \\
15 \\
18 \\
9 \\
10 \\
4 \\
5 \\
2 \\
2 \\
1 \\
1 \\
1\end{array}$ & $\begin{array}{r}8 \\
22 \\
19 \\
10 \\
11 \\
20 \\
64 \\
131 \\
54 \\
153 \\
191 \\
364 \\
189 \\
240 \\
119 \\
129 \\
48 \\
69 \\
28 \\
24 \\
-\overline{13} \\
14\end{array}$ & $\begin{array}{r}8.0 \\
11.0 \\
9.5 \\
10.0 \\
11.0 \\
10.0 \\
10.7 \\
11.9 \\
10.8 \\
11.8 \\
11.9 \\
12 \cdot 6 \\
12 \cdot 6 \\
13.3 \\
13.2 \\
12.9 \\
12.0 \\
13 \cdot 8 \\
14.0 \\
12.0 \\
-.0 \\
13.0 \\
14.0\end{array}$ \\
\hline Total & 156 & 1920 & $12 \cdot 3$ \\
\hline
\end{tabular}

\section{NUMBER OF VIABLE FOETUSES}

The mean number of viable foetuses in the eighty rats of Group 2 was found to be $10 \cdot 1 \pm 0 \cdot 25$, and the individual numbers ranged from 1 to 16 . In thirty-four $(43 \%)$ pregnancies either ten or eleven foetuses were found, while only five $(6 \%)$ had fewer than eight. It was noticeable that in no pregnancy in which implantation occurred were all the embryos lost before Days 18 to 20 of pregnancy.

In the eighty rats that were allowed to carry their litters almost to term, a statistical analysis was performed to determine whether there were any significant differences in the number of ovulations, the number of implantation sites or the number of viable foetuses, between left and right sides of the reproductive tract. None of these differences was significant. 
EFFECT OF BODY WEIGHT ON THE NUMBER OF EGGS OVULATED

The body weights, recorded on the day of ovulation, of the 156 rats in Groups 2 and 3 were divided into weight ranges of $5 \mathrm{~g}$. The mean number of eggs shed was calculated for each weight group, at intervals of $5 \mathrm{~g}$ throughout the range as shown in Table 3. A highly significant relationship was observed $(P<0.001)$. The regression line is given by the formula: $y=8 \cdot 775+0.2112 x$ (where $y=$ mean number of eggs ovulated, and $x=$ weight range of the rats: in this case 131 to $135 \mathrm{~g}=0$ and 261 to $265 \mathrm{~g}=26$ ), and the slope of the regression is given by: $b=0 \cdot 2112 \pm 0 \cdot 0345$.

\section{AMOUNT AND DISTRIBUTION OF PRENATAL MORTALITY}

\section{Loss of whole litters}

In fourteen $(7 \cdot 1 \%)$ out of the total of 196 rats which were found to have spermatozoa in the vaginal smear on the morning of Day 1, no embryos implanted. Eleven rats of Group 3 in which either implantation had not occurred or the sites were not visible at laparotomy on Days 5 and 6, were all found to be pregnant at autopsy on Days 18 to 20 of pregnancy.

Thus in $7 \cdot 1 \%$ of all rats mated, total loss of eggs occurred before implantation. This may have been due to failure of fertilization of all the eggs, and these rats have been excluded from the estimates of prenatal mortality presented below.

\section{TABLE 4}

EGGS RECOVERED FROM UTERI OF TWENTY-TWO RATS KILLED ON DAY 5 OF PREGNANCY AND CLASSIFIED ACCORDING TO THEIR STAGE OF DEVELOPMENT

\begin{tabular}{l|c|c|c|c|c}
\hline & $\begin{array}{c}\text { Degenerate } \\
\text { eggs* }\end{array}$ & \multicolumn{2}{|c|}{ Fertilized eggs } & \multicolumn{2}{c}{ Total eggs } \\
\cline { 2 - 5 } \cline { 5 - 6 } & 14 & Morulae & Blastocysts & Recovered & Shed \\
\hline $\begin{array}{l}\text { No. eggs } \\
\% \text { of total recovered }\end{array}$ & 7.5 & 12 & 161 & 187 & 242 \\
\hline
\end{tabular}

* Degenerate eggs found at this stage of pregnancy were assumed to be unfertilized eggs, in which the cytoplasm had become divided into masses of unequal size.

\section{Partial loss of litters-pre-implantation loss}

A total of 187 eggs was recovered from the uteri of the twenty-two (Group 1) rats which were killed on Day 5 of pregnancy and possessed some normally developing eggs. A classification of the stage of development of these recovered eggs is shown in Table 4 . Loss amounted to $13.9 \%$ of the eggs recovered, of which $53 \%$ was due to eggs which failed to become fertilized, and $47 \%$ due to fertilized eggs which failed to develop into blastocysts.

When the pre-implantation loss for this group of animals is expressed as a percentage of the eggs shed, it only amounts to 10.8 comparing well with the estimates given for Groups 2 and 3 in Table 5. However, there is no reason to suppose that there was a differential loss of non-viable eggs during recovery 
from the uterus; therefore it may be more exact to express the number of eggs lost as a percentage of the eggs recovered.

A total of 918 corpora lutea was counted on the ovaries of the seventy-six rats killed on Day 8 of pregnancy, but there were only 830 implantation sites in the uteri. In two animals the implantation sites exceeded by one the number of corpora lutea, probably due to the occurrence of polyovuly. Of the 918 eggs ovulated, only ninety $(9.8 \%)$ failed to implant.

A total of 856 corpora lutea was counted on the ovaries of the sixty-nine rats that were laparotomized between Days 7 and 16 of pregnancy, but only 755 implantation sites were observed. Of these corpora lutea $101(11.8 \%)$ were not represented by implantation sites.

TABLE 5

NUMBER AND PERGENTAGE OF EGGS LOST BEFORE IMPLANTATION

\begin{tabular}{|c|c|c|c|c|c|c|}
\hline \multirow{2}{*}{ No. rats } & \multicolumn{2}{|c|}{ Corpora lutea } & \multicolumn{2}{|c|}{ Implantation sites } & \multirow{2}{*}{$\begin{array}{l}\text { Corpora lutea } \\
\text { not represented by } \\
\text { implantation sites }\end{array}$} & \multirow{2}{*}{$\begin{array}{l}\text { Loss of } \\
\text { eggs } \\
(\%)\end{array}$} \\
\hline & Total & Mean \pm s.E. & Total & Mean \pm s.E. & & \\
\hline $\begin{array}{l}76 \text { (Group 2) } \\
69 \text { (Group 3) }\end{array}$ & $\begin{array}{l}918 \\
856\end{array}$ & $\begin{array}{l}12 \cdot 1 \pm 0 \cdot 24 \\
12 \cdot 5 \pm 0.22\end{array}$ & $\begin{array}{l}830 \\
755\end{array}$ & $\begin{array}{l}10 \cdot 9 \pm 0.25 \\
10 \cdot 9 \pm 0.25\end{array}$ & $\begin{array}{l}90^{*} \\
101\end{array}$ & $\begin{array}{r}9 \cdot 8 \\
11 \cdot 8\end{array}$ \\
\hline 145 (Total) & 1774 & $12 \cdot 2 \pm 0 \cdot 18$ & 1585 & $10 \cdot 9 \pm 0 \cdot 19$ & 191 & $10 \cdot 8$ \\
\hline
\end{tabular}

* In two litters one implantation site more than the number of corpora lutea was recorded.

To ensure as accurate an assessment of the amount of pre-implantation loss as possible the figures for these two groups of animals have been combined (Table 5). The overall figure for the percentage loss of eggs before implantation was 10.8. The amount of individual pre-implantation loss for these 145 pregnancies ranged from 0 to $83 \%$. In sixty-six $(46 \%)$ of the 145 litters no pre-implantation loss occurred, and in fifty-eight $(40 \%)$ pregnancies the loss was less than $20 \%$. In a further seventeen (12\%) animals the percentage loss ranged from 20 to 50 . In only four (3\%) pregnancies in which some eggs implanted, did the loss of eggs before implantation exceed $50 \%$.

Although some eggs were lost before implantation in $55 \%$ out of the 145 pregnancies studied, only $10 \cdot 8 \%$ of the 1774 eggs ovulated failed to implant. It was observed that the percentage of litters showing loss ranged from 25 when nine eggs were ovulated to 75 when sixteen eggs were ovulated. The percentage of eggs lost ranged from $2 \cdot 8$ when nine eggs were shed to $24 \cdot 2$ with fifteen ovulations. This suggested that both the percentage of litters showing loss and the percentage of eggs lost increased with increasing numbers of ovulations.

In Table 6 the data are presented to show the relationship between the number of eggs ovulated by a single ovary and the percentage of the eggs, from that ovary, that fail to implant. It would appear that as the number of eggs ovulated by a single ovary increases, so does the percentage that are lost. A regression analysis shows that this correlation is significant $(P<0.05)$ and the formula for the regression is : $y=2 \cdot 222+1.984 x$ (where $y=$ percentage of eggs 
lost transformed to the equivalent angle* and $x=$ number of eggs ovulated) and the slope of the regression is given by: $b=1.984 \pm 0.683$ (for an angular transformation*).

It has been shown that the percentage of eggs lost before implantation increases as the number of eggs shed by a single ovary increase. In order to test whether the number of eggs shed by one ovary also affected the number of eggs lost in the opposite uterine horn, the data for all the 145 pregnancies studied in Table 6 were re-arranged, so that a comparison could be made of the amount of loss in all the uterine horns into which a constant number of eggs passed, in relation to the number of eggs in the opposite horn. Regression analyses were performed on the percentages of eggs lost on that side with the constant number

TABLE 6

RELATIONSHIP BETWEEN THE NUMBER OF GORPORA LUTEA ON ONE OVARY AND THE PERGENTAGE OF THEIR EGGS LOST BEFORE IMPLANTATION

\begin{tabular}{c|c|c|c|c}
\hline $\begin{array}{c}\text { No. } \\
\text { corpora lutea }\end{array}$ & $\begin{array}{c}\text { No. } \\
\text { ovaries }\end{array}$ & $\begin{array}{c}\text { Total } \\
\text { eggs }\end{array}$ & $\begin{array}{c}\text { Total } \\
\text { implantations }\end{array}$ & $\begin{array}{c}\text { Eggs lost } \\
(\%)\end{array}$ \\
\cline { 1 - 2 } 1 & 1 & 1 & 1 & $0 \cdot 0$ \\
2 & 9 & 18 & 17 & $5 \cdot 6$ \\
3 & 19 & 57 & 56 & $1 \cdot 8$ \\
4 & 31 & 124 & 117 & $5 \cdot 6$ \\
5 & 44 & 220 & 210 & $4 \cdot 5$ \\
6 & 64 & 384 & 324 & $15 \cdot 6$ \\
7 & 58 & 406 & 379 & $6 \cdot 7$ \\
8 & 30 & 240 & 208 & $13 \cdot 3$ \\
9 & 22 & 198 & 162 & $22 \cdot 2$ \\
10 & 9 & 90 & 78 & $15 \cdot 4$ \\
11 & 1 & 11 & 11 & $0 \cdot 0$ \\
12 & 1 & 12 & 8 & $33 \cdot 3$ \\
13 & 1 & 13 & 12 & $7 \cdot 7$ \\
\hline Total & 290 & 1774 & 1583 & $10 \cdot 8$ \\
\hline
\end{tabular}

of ovulations, in relation to the increase in the number of corpora lutea on the opposite side. None of these was found to be significant. Furthermore, it was found, as was to be expected if the factors causing loss were only operating locally, that in the majority of cases the greater percentage of eggs was lost on that side on which the greater number was ovulated.

Bowman \& Roberts (1958) have shown that in mice, while there is a significant relationship between loss of eggs before implantation and the number of eggs ovulated, the percentage of eggs failing to become fertilized is unaffected by the number ovulated. This suggests that the failure of some eggs to develop into blastocysts may be correlated with the number of eggs present in the uterus at this critical stage of development. Since data on the failure of fertilization are not available for these 145 individual animals, further analysis of these results is not possible, but it was possible to analyse the data obtained from the twenty-two (Group 1) rats killed on Day 5 of pregnancy. The number and

* This regression was calculated on figures obtained by converting all percentages to angles according to Table 10 (Fisher \& Yates, 1957). 
percentage of eggs (a) failing to become fertilized and (b) failing to develop into blastocysts is set out in Table 7 in relation to the number of eggs shed by each ovary. In this small sample no significant correlations were observed, whether the two classes of degenerating eggs were expressed as percentages of eggs recovered or as percentages of eggs shed.

On the evidence presented, it must be concluded that the percentage of eggs lost before implantation is related to the total number of eggs ovulated, but that the majority of the loss occurs on that side on which the greater number of eggs is ovulated. Therefore it must be assumed that pre-implantation loss is not due to systemic factors, but to factors such as crowding of the developing eggs, which operate locally in each individual uterine horn.

TABLE 7

PERCENTAGE OF EGGS NOT FERTILIZED AND PERCENTAGE FAILING TO BECOME BLASTOGYSTS, IN RELATION TO THE NUMBER OF EGGS SHED FROM A SINGLE OVARY

\begin{tabular}{|c|c|c|c|c|c|c|c|c|c|}
\hline \multirow{3}{*}{$\begin{array}{l}\text { No. } \\
\text { eggs } \\
\text { shed } \\
\text { per } \\
\text { ovary }\end{array}$} & \multirow{3}{*}{$\begin{array}{l}\text { No. } \\
\text { uteri }\end{array}$} & \multicolumn{8}{|c|}{ Eggs } \\
\hline & & \multicolumn{2}{|c|}{ Total } & \multicolumn{3}{|c|}{ Unfertilized } & \multicolumn{3}{|c|}{ Failed to form blastocysts } \\
\hline & & Shed $(A)$ & Recovered $(B)$ & No. & $\%$ of $(A)$ & $\%$ of $(B)$ & No. & $\%$ of $(A)$ & $\%$ of $(B)$ \\
\hline $\begin{array}{r}\leqslant 3 \\
4 \\
5 \\
6 \\
7 \\
8\end{array}$ & $\begin{array}{r}9 \\
5 \\
5 \\
12 \\
3 \\
10\end{array}$ & $\begin{array}{l}24 \\
20 \\
25 \\
72 \\
21 \\
80\end{array}$ & $\begin{array}{l}13 \\
16 \\
17 \\
60 \\
20 \\
61\end{array}$ & $\begin{array}{l}0 \\
4 \\
2 \\
6 \\
0 \\
2\end{array}$ & $\begin{array}{r}0 \\
20 \\
8 \\
8 \\
0 \\
3\end{array}$ & $\begin{array}{r}0 \\
25 \\
12 \\
10 \\
0 \\
3\end{array}$ & $\begin{array}{l}0 \\
0 \\
3 \\
2 \\
0 \\
6\end{array}$ & $\begin{array}{r}0 \\
0 \\
12 \\
3 \\
0 \\
8\end{array}$ & $\begin{array}{r}0 \\
0 \\
18 \\
3 \\
0 \\
10\end{array}$ \\
\hline Total & 44 & 242 & 187 & 14 & 6 & 8 & 12 & 5 & 6 \\
\hline
\end{tabular}

The mean amounts of prenatal mortality in the sixty-nine (Group 3) rats that were subjected to laparotomy between Days 7 and 16 of pregnancy are set out according to day of laparotomy in Table 8. It can be seen that the mean percentage pre-implantation loss is $11.8 \pm 1.97$, and that the group means range from 2.9 to $22.5 \%$. These figures are in general relatively low; in only four groups do the mean values exceed $11 \%$. A statistical analysis showed that there was no significant trend in the group mean percentage losses of eggs before implantation when considered in relation to day of laparotomy. The fact that some groups showed rather high mean values for percentage loss of eggs may be due to some individual animals which showed excessive loss. The figures for individual pre-implantation loss in these sixty-nine rats ranged from 0 to $83 \%$.

\section{Partial loss of litters-post-implantation loss}

An estimate of the amount of post-implantation loss can only be made for the sixty-nine (Group 3) rats that were laparotomized between Days 7 and 16 of pregnancy. The mean percentage losses after implantation for groups of rats operated upon on various days of pregnancy are shown in Table 8. A statistical analysis failed to show any trend towards a greater amount of loss in the later laparotomy groups. However, the two rats that had to be excluded from the 
results because the laparotomy procedures caused regression of many of the embryos, were subjected to laparotomy on Days 13 and 15, respectively. A further loss of $7 \cdot 7 \pm 1.07 \%$ of the original number of corpora lutea occurred after implantation. The mean post-implantation losses for the various laparotomy groups ranged from $3 \cdot 0$ to $15 \cdot 7 \%$ (Table 8 ).

TABLE 8

AMOUNT AND DISTRIBUTION OF EMBRYONIC LOSS IN EIGHTY RATS AGCORDING TO THE DAY OF PREGNANCY

\begin{tabular}{|c|c|c|c|c|c|c|c|}
\hline $\begin{array}{c}\text { Day } \\
\text { of } \\
\text { laparotomy }\end{array}$ & $\begin{array}{c}\text { No. } \\
\text { preg. } \\
\text { nancies }\end{array}$ & $\begin{array}{c}\text { Mean No. } \\
\text { corpora } \\
\text { lutea }\end{array}$ & $\begin{array}{c}\text { Mean No. } \\
\text { implantation } \\
\text { sites }\end{array}$ & $\begin{array}{c}\text { Pre- } \\
\text { implantation } \\
\text { loss }(\%)\end{array}$ & $\begin{array}{c}\text { Mean No. } \\
\text { viable } \\
\text { foetuses }\end{array}$ & $\begin{array}{c}\text { Post- } \\
\text { implantation } \\
\text { loss }(\%)\end{array}$ & $\begin{array}{l}\text { Total } \\
\text { loss } \\
(\%)\end{array}$ \\
\hline $\begin{array}{c}5 \\
6 \\
7 \\
8 \\
9 \\
10 \mathrm{a} \\
10 \mathrm{~b} \\
11 \mathrm{a} \\
11 \mathrm{~b} \\
12 \\
13 \\
14 \\
15 \\
16\end{array}$ & $\begin{array}{l}5 \\
6 \\
5 \\
5 \\
6 \\
6 \\
6 \\
7 \\
5 \\
5 \\
5 \\
6 \\
7 \\
6\end{array}$ & $\begin{array}{l}13.6 \\
13.0 \\
12.8 \\
11.8 \\
12.8 \\
11.8 \\
14.0 \\
11.0 \\
13.8 \\
12.6 \\
13.6 \\
11.5 \\
12.7 \\
11.0\end{array}$ & $\begin{array}{r}- \\
- \\
11 \cdot 4 \\
11 \cdot 0 \\
10 \cdot 0 \\
11 \cdot 0 \\
13 \cdot 3 \\
10 \cdot 3 \\
12 \cdot 4 \\
12 \cdot 0 \\
10 \cdot 6 \\
11 \cdot 2 \\
9 \cdot 9 \\
9 \cdot 0\end{array}$ & \begin{tabular}{r}
\multicolumn{1}{c}{-} \\
$10 \cdot 9$ \\
$6 \cdot 8$ \\
$22 \cdot 1$ \\
$7 \cdot 0$ \\
$4 \cdot 1$ \\
$6 \cdot 5$ \\
$9 \cdot 0$ \\
$4 \cdot 8$ \\
$22 \cdot 1$ \\
$2 \cdot 9$ \\
$22 \cdot 5$ \\
$18 \cdot 2$
\end{tabular} & $\begin{array}{r}9.4 \\
11.8 \\
9.4 \\
10.4 \\
9.3 \\
10.3 \\
12.5 \\
9.4 \\
10.8 \\
11.4 \\
9.6 \\
10.2 \\
8.4 \\
8.7\end{array}$ & $\begin{array}{r}- \\
- \\
15.7 \\
5.1 \\
5.2 \\
5.7 \\
5.9 \\
7.8 \\
12.7 \\
4.7 \\
7.3 \\
8.7 \\
11.2 \\
3.0\end{array}$ & $\begin{array}{r}30.9 \\
9.0 \\
26.6 \\
11.9 \\
27.3 \\
12.7 \\
10.0 \\
14.3 \\
21.7 \\
9.5 \\
29.4 \\
11.6 \\
33.7 \\
21.2\end{array}$ \\
\hline Mean & & $12 \cdot 5$ & $10.9 *$ & $11.8^{*}$ & $10 \cdot 1$ & $7 \cdot 7 *$ & $19 \cdot 5$ \\
\hline
\end{tabular}

* For sixty-nine pregnancies.

TABLE 9

PERGENTAGE OF LITTERS SHOWING LOSS AND PERGENTAGE OF EMBRYOS LOST

\begin{tabular}{c|c|c|c|c}
\hline \multirow{2}{*}{ No. sites } & \multicolumn{3}{|c|}{ Litters } & \multicolumn{2}{|c}{ Embryos or foetuses } \\
\cline { 2 - 3 } \cline { 5 - 5 } & Total & Showing loss & Total & \multicolumn{2}{|c}{ Lost } \\
\hline 57 & 5 & $2(40) *$ & 28 & $2(7) \dagger$ \\
8 & 4 & $2(50)$ & 32 & $4(13)$ \\
9 & 6 & $3(50)$ & 54 & $7(13)$ \\
10 & 10 & $4(40)$ & 100 & $7(7)$ \\
11 & 17 & $7(41)$ & 187 & $9(5)$ \\
12 & 11 & $8(73)$ & 132 & $12(9)$ \\
13 & 7 & $5(71)$ & 91 & $10(11)$ \\
$\geqslant 14$ & 9 & $7(78)$ & 131 & $15(11)$ \\
\hline Total & 69 & $38(55)$ & 755 & $66(8 \cdot 7)$ \\
\hline
\end{tabular}

* Percentage of litters showing loss in parentheses.

$\uparrow$ Percentage of embryos or foetuses lost in parentheses.

The relationship between the number of embryos or foetuses lost and the number of eggs that implanted is summarized in Table 9 , where the proportion of litters showing loss and the proportion of embryos lost are set out. In thirtyeight $(55 \%)$ out of a total of sixty-nine pregnant animals some loss after 
implantation occurred, and sixty-six $(8.7 \%)$ out of the 755 eggs that implanted failed to survive to the end of pregnancy. A statistical analysis showed that the percentage of embryos lost appeared to be unaffected by the number of eggs implanting.

The relationships between the number of eggs implanting in a single uterine horn and the total percentage of those embryos or foetuses lost, and also the percentages lost during early, middle or late pregnancy, are shown in Table 10. Regression analyses showed that there were no significant correlations between the number of implantations in one uterine horn and either the total percentage of those embryos lost, or the percentage lost during early pregnancy. However, the relationship between the number of implantations in one uterine horn and

TABLE 10

RELATIONSHIP BETWEEN THE NUMBER OF EGGS IMPLANTING IN ONE UTERINE HORN AND THE NUMBER AND PERGENTAGE OF EMBRYOS DYING DURING PREGNANGY

\begin{tabular}{|c|c|c|c|c|c|c|c|c|c|c|}
\hline \multirow{3}{*}{$\begin{array}{l}\text { Implantation } \\
\text { sites in one } \\
\text { uterine horn }\end{array}$} & \multirow{3}{*}{$\begin{array}{l}\text { No. } \\
\text { uterine } \\
\text { horns }\end{array}$} & \multirow{3}{*}{$\begin{array}{l}\text { Total No. } \\
\text { implantation } \\
\text { sites }\end{array}$} & \multicolumn{8}{|c|}{ Embryos or foetuses dead } \\
\hline & & & \multicolumn{2}{|c|}{ Early } & \multicolumn{2}{|c|}{ Middle } & \multicolumn{2}{|c|}{ Late } & \multicolumn{2}{|c|}{ Total } \\
\hline & & & No. & $\%$ & No. & $\%$ & No. & $\%$ & $\mathcal{N} o$. & $\%$ \\
\hline $\begin{array}{r}0 \\
1 \\
2 \\
3 \\
4 \\
5 \\
6 \\
7 \\
8 \\
9 \\
\Rightarrow 10\end{array}$ & $\begin{array}{r}1 \\
6 \\
5 \\
11 \\
14 \\
30 \\
27 \\
27 \\
10 \\
3 \\
4\end{array}$ & $\begin{array}{r}0 \\
6 \\
10 \\
33 \\
56 \\
150 \\
162 \\
189 \\
80 \\
27 \\
42\end{array}$ & $\begin{array}{r}0 \\
1 \\
0 \\
5 \\
3 \\
12 \\
10 \\
8 \\
5 \\
2 \\
2\end{array}$ & $\begin{array}{r}0 \\
17 \\
0 \\
15 \\
5 \\
8 \\
6 \\
4 \\
6 \\
7 \\
5\end{array}$ & $\begin{array}{l}0 \\
0 \\
0 \\
0 \\
0 \\
5 \\
3 \\
2 \\
1 \\
0 \\
2\end{array}$ & $\begin{array}{l}0 \\
0 \\
0 \\
0 \\
0 \\
3 \\
2 \\
1 \\
1 \\
0 \\
5\end{array}$ & $\begin{array}{l}0 \\
0 \\
0 \\
0 \\
0 \\
3 \\
0 \\
1 \\
1 \\
0 \\
0\end{array}$ & $\begin{array}{l}0 \\
0 \\
0 \\
0 \\
0 \\
2 \\
0 \\
1 \\
1 \\
0 \\
0\end{array}$ & $\begin{array}{r}0 \\
1 \\
0 \\
5 \\
3 \\
20 \\
13 \\
11 \\
7 \\
2 \\
4\end{array}$ & $\begin{array}{r}0 \\
17 \\
0 \\
15 \\
5 \\
13 \\
8 \\
6 \\
9 \\
7 \\
10\end{array}$ \\
\hline Total & 138 & 755 & 48 & 6 & 13 & 2 & 5 & 1 & 66 & $8 \cdot 7$ \\
\hline
\end{tabular}

the percentage of the embryos which died during middle pregnancy approached significance $(P>0.05)$. No analysis was performed on the data regarding the percentage of foetuses dying during late pregnancy, since the number of foetuses involved was rather small.

In an attempt to assess more accurately the effect of uterine crowding on the number of embryos dying during middle pregnancy, the same re-arrangement of the data that was used by McLaren \& Michie (1959) and Adams (1962) was followed. All the embryos dying during the early period were subtracted from the number of implantations present in the uterine horn at the start of the middle period. The relationship between the numbers of implantations surviving until middle pregnancy and the number of middle deaths again just failed to reach the level of significance $(P<0 \cdot 1)$. The paucity of late deaths made analysis impossible, but it is interesting that all the loss of foetuses occurred in horns containing between three and six foetuses. None of the thirty-six uterine horns containing between seven and ten foetuses suffered loss.

The data presented in Table 10 show that most embryonic loss occurs during 
early pregnancy (before Day 11) and that the amount of this early loss is not influenced by the number of eggs implanting in the uterus. A further analysis has shown that large total numbers of implants, even when unevenly divided between both uterine horns, have no effect on the percentage of embryos lost. Forty-eight $(73 \%)$ of the sixty-six embryos or foetuses that failed to survive in these sixty-nine pregnancies died before Day 11 of pregnancy, at a time when uterine overcrowding in a physical sense was not affecting their development. Although only thirteen (20\%) embryos died during middle pregnancy (between Days 11 and 13), their loss, however, may in part be attributable to overcrowding in the uterus.

TABLE 11

FATE OF 613 IMPLANTATION SITES MEASURED AT LAPAROTOMY; MEAN DIAMETER"OF SITES ACCORDING TO DAY OF PREGNANCY

\begin{tabular}{|c|c|c|c|c|c|c|c|c|}
\hline \multirow{3}{*}{$\begin{array}{c}\text { Stage of } \\
\text { pregnancy } \\
\text { (days) }\end{array}$} & \multirow{3}{*}{$\begin{array}{c}\text { No. } \\
\text { preg- } \\
\text { nancies }\end{array}$} & \multirow{2}{*}{\multicolumn{3}{|c|}{ Implantation sites }} & \multicolumn{4}{|c|}{ Diameter of implantation sites $(\mathrm{mm})$} \\
\hline & & & & & \multicolumn{2}{|c|}{ Survived* } & \multicolumn{2}{|c|}{ Regressed } \\
\hline & & Total & Survived* & Regressed & Mean \pm S.E. & Range & Mean & Range \\
\hline $\begin{array}{l}7 \\
8 \\
9 \\
10 \mathrm{a} \\
11 \mathrm{a} \\
12 \\
13 \\
14 \\
15 \\
16\end{array}$ & $\begin{array}{l}5 \\
5 \\
6 \\
6 \\
7 \\
5 \\
5 \\
6 \\
7 \\
6\end{array}$ & $\begin{array}{l}57 \\
55 \\
60 \\
66 \\
72 \\
60 \\
53 \\
67 \\
69 \\
54\end{array}$ & $\begin{array}{l}47 \\
52 \\
56 \\
62 \\
66 \\
57 \\
48 \\
61 \\
59 \\
52\end{array}$ & $\begin{array}{r}10 \\
3 \\
4 \\
4 \\
6 \\
3 \\
5 \\
6 \\
10 \\
2\end{array}$ & $\begin{array}{r}2 \cdot 41 \pm 0.022 \\
2 \cdot 85 \pm 0 \cdot 023 \\
3 \cdot 23 \pm 0 \cdot 018 \\
3 \cdot 77 \pm 0 \cdot 031 \\
4 \cdot 37 \pm 0 \cdot 043 \\
5 \cdot 26 \pm 0 \cdot 039 \\
6 \cdot 94 \pm 0.033 \\
8 \cdot 04 \pm 0 \cdot 043 \\
9 \cdot 07 \pm 0.060 \\
10 \cdot 26 \pm 0 \cdot 044\end{array}$ & $\begin{array}{l}2 \cdot 0 \text { to } 2 \cdot 8 \\
2.4 \text { to } 3 \cdot 4 \\
2 \cdot 9 \text { to } 3 \cdot 5 \\
3 \cdot 3 \text { to } 4 \cdot 8 \\
3.7 \text { to } 5 \cdot 0 \\
4.3 \text { to } 5 \cdot 9 \\
6.2 \text { to } 7 \cdot 8 \\
7.2 \text { to } 8 \cdot 7 \\
8.2 \text { to } 10 \cdot 4 \\
9 \cdot 6 \text { to } 10 \cdot 4\end{array}$ & $\begin{array}{l}2 \cdot 29 \\
2 \cdot 77 \\
3 \cdot 03 \\
3 \cdot 35 \\
4 \cdot 35 \\
5 \cdot 03 \\
6 \cdot 02 \\
4 \cdot 53 \\
5 \cdot 42 \\
3 \cdot 60\end{array}$ & $\begin{array}{l}2.1 \text { to } 2.4 \\
2.7 \text { to } 2.9 \\
2.8 \text { to } 3.5 \\
2.9 \text { to } 3.6 \\
3.9 \text { to } 5.2 \\
4.2 \text { to } 5.5 \\
4.4 \text { to } 7.1 \\
3.3 \text { to } 5.2 \\
3.6 \text { to } 9.4 \\
2.0 \text { to } 5.2\end{array}$ \\
\hline Total & & 613 & 560 & 53 & & & & \\
\hline$\%$ of total & & - & $91 \cdot 4$ & $8 \cdot 6$ & & & & \\
\hline
\end{tabular}

* Viable foetuses at autopsy.

The diameters of 613 implantation sites were measured at laparotomy on Days 7 to 16 of pregnancy. The mean diameters of those sites which survived to the end of pregnancy, and of those which regressed before the end, have been calculated for each day of pregnancy and are shown in Table 11. It is clear that the mean diameter of the sites which survive increases throughout pregnancy, particularly after Day 12. On the other hand, the mean diameter of those sites which are either going to regress or are regressing increases only up to Day 13. These mean diameters are shown in Text-fig. 3. It is only at the stage when the swellings begin to increase very rapidly in size that the divergence between the growth curves of those sites that will survive and those that will degenerate becomes significantly different.

The relationship between the diameter at laparotomy of the implantation sites that regress and their subsequent fate are shown in Table 12. The fate of the sites has been classified as follows: (a) no trace, (b) mole, (c) atrophic placenta and (d) dead foetus. Categories (a) and (b) represent sites that contain embryos which die before Day 11 of pregnancy, category (c) represents embryos 
that die between Days 11 and 13, and category (d) foetuses that die after Day 13. There are no significant differences between the figures for the mean diameters of the sites that are destined to give rise to moles, atrophic placentae, or viable foetuses up to Day 11. After Day 11 the curve representing the mean diameter of the sites which give rise to moles begins to diverge from those of the other two classifications. After Day 13 the curve representing the sites which give rise to atrophic placentae also begins to diverge from that representing the viable embryos. These relationships are shown diagrammatically in Textfig. 4.

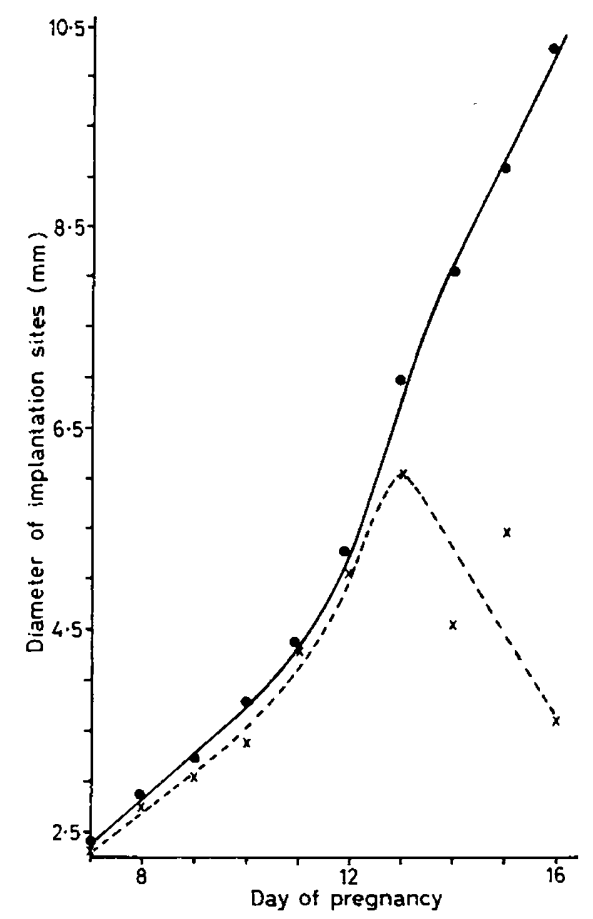

Texr-FIG. 3. The relationship between the diameter of the implantation sites and day of pregnancy, and their ultimate fate.

Implantation sites that survive to term.
Implantation sites that regress before term.

These curves provide good evidence for the accuracy of estimates of the time of death of the embryos according to the remnants found in the uterus at autopsy. It can be seen from Table 12 that the mean diameter of moles reaches its peak on Day 13, when it is similar to the mean diameter which those sites classified as normal reach on Day 12. The sites giving rise to atrophic placentae reach their greatest mean diameter on Day 15, equivalent to the mean diameter on Day 14, of the sites that ultimately survive with viable foetuses. Thus in both of these cases of regressing sites their peak size is reached 2 days after the last day on which it has been assumed that their associated embryo might have died. Their size at this time is, in fact, only equivalent to a further $24 \mathrm{hr}$ growth of 'normal' sites. It is noteworthy that the mean diameters of those sites that 
Prenatal mortality in the rat

Table 12

REGRESSING IMPLANTATION SITES: RELATION BETWEEN DIAMETER (MM) AT LAPAROTOMY AND ULTIMATE FATE OF CONCEPTUS

\begin{tabular}{|c|c|c|c|c|c|c|c|c|}
\hline \multirow{3}{*}{$\begin{array}{c}\text { Day of } \\
\text { pregnancy }\end{array}$} & \multicolumn{8}{|c|}{ Fate of implantation site } \\
\hline & \multicolumn{2}{|c|}{ No trace } & \multicolumn{2}{|c|}{ Mole } & \multicolumn{2}{|c|}{ Atrophic placenta } & \multicolumn{2}{|c|}{ Dead foetus } \\
\hline & No. & $\begin{array}{c}\text { Mean } \\
\text { diameter }\end{array}$ & No. & $\begin{array}{c}\text { Mean } \\
\text { diameter }\end{array}$ & No. & $\begin{array}{c}\text { Mean } \\
\text { diameter }\end{array}$ & No. & $\begin{array}{c}\text { Mean } \\
\text { diameter }\end{array}$ \\
\hline $\begin{array}{c}7 \\
8 \\
9 \\
10 \mathrm{a} \\
11 \mathrm{a} \\
12 \\
13 \\
14 \\
15 \\
16\end{array}$ & $\begin{array}{l}0 \\
0 \\
3 \\
0 \\
0 \\
0 \\
0 \\
1 \\
0 \\
0\end{array}$ & $\begin{array}{c}- \\
\overline{-} \\
2 \cdot 87 \\
- \\
= \\
= \\
\overline{-} \\
3 \cdot 30 \\
= \\
-\end{array}$ & $\begin{array}{l}8 \\
2 \\
0 \\
4 \\
5 \\
2 \\
2 \\
5 \\
7 \\
1\end{array}$ & $\begin{array}{l}2 \cdot 30 \\
2 \cdot 70 \\
- \\
3 \cdot 35 \\
4 \cdot 22 \\
4 \cdot 80 \\
5 \cdot 20 \\
4 \cdot 78 \\
3 \cdot 97 \\
2 \cdot 00\end{array}$ & $\begin{array}{l}2 \\
1 \\
1 \\
0 \\
0 \\
1 \\
3 \\
0 \\
1 \\
1\end{array}$ & $\begin{array}{c}2 \cdot 35 \\
2 \cdot 90 \\
3 \cdot 50 \\
- \\
- \\
5 \cdot 50 \\
6.57 \\
- \\
8 \cdot 00 \\
5 \cdot 20\end{array}$ & $\begin{array}{l}0 \\
0 \\
0 \\
0 \\
1 \\
0 \\
0 \\
0 \\
2 \\
0\end{array}$ & $\begin{array}{c}- \\
- \\
- \\
5 \cdot 20 \\
= \\
- \\
\overline{-} \\
9 \cdot 20 \\
-\end{array}$ \\
\hline Total (613) & 4 & - & 36 & - & 10 & - & 3 & - \\
\hline$\%$ of total & - & 0.7 & - & $5 \cdot 9$ & - & 1.6 & - & 0.5 \\
\hline
\end{tabular}

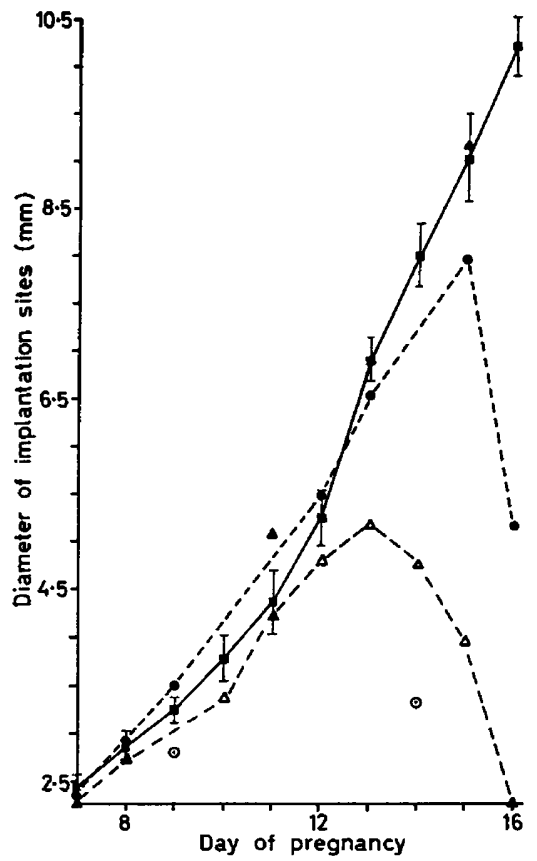

TExT-FIG. 4. The relationship between the stage of death of the embryo and its diameter.

Mean diameters \pm s.e. (vertical bars) of implantation sites surviving to viable foetuses.

Mean diameters of implantation sites giving rise to atrophic placentae.

$\Delta---\Delta \quad$ Mean diameters of implantation sites giving rise to moles.

A Mean diameters of implantation sites giving rise to dead foetuses.

- Mean diameters of implantation sites that disappear without trace. 
disappear without trace are always smaller, and the mean diameters of those sites giving rise to dead foetuses are always larger, than those of any of the other classifications.

From the data presented in Table 12, it can be seen that of the total number of fifty-three sites which failed to survive, no trace could be found of $7.5 \%$, moles were all that remained of $67.9 \%$, atrophic placentae were observed in $18.9 \%$, and $5.7 \%$ accommodated dead foetuses.

Loss of embryos after implantation in individual pregnancies ranged from 0 to $33 \%$ of the original number of ovulations. No embryonic losses were observed in thirty-one $(45 \%)$ of the sixty-nine pregnancies studied, but in thirty-three $(48 \%)$ pregnancies loss ranged from $0 \cdot 1$ to $20 \%$. In only five $(7 \%)$ rats did embryonic loss exceed $20 \%$, and in no case did it exceed $33 \%$.

\section{TABLE 13}

PERGENTAGE OF LITTERS SHOWING PRENATAL LOSS, AND THE PERGENTAGE OF EGGS AND EMBRYOS LOST, IN RELATION TO THE NUMBER OF OVULATIONS

\begin{tabular}{c|c|c|c|c}
\hline \multirow{2}{*}{$\begin{array}{c}\text { No. } \\
\text { eggs } \\
\text { ovulated }\end{array}$} & \multicolumn{3}{|c|}{ Litters } & \multicolumn{2}{c}{ Eggs and embryos } \\
\cline { 2 - 4 } & Total & No. showing loss & Total & No. lost \\
\hline 8 & 1 & $0(0)^{*}$ & 8 & $0(0) \dagger$ \\
9 & 3 & $1(33)$ & 27 & $1(4)$ \\
10 & 4 & $3(75)$ & 40 & $8(20)$ \\
11 & 14 & $9(64)$ & 154 & $24(16)$ \\
12 & 20 & $17(85)$ & 240 & $36(15)$ \\
13 & 18 & $15(83)$ & 234 & $52(22)$ \\
14 & 8 & $6(75)$ & 112 & $13(12)$ \\
15 & 5 & $4(80)$ & 75 & $29(39)$ \\
16 & 7 & $6(86)$ & 112 & $32(29)$ \\
\hline Total & 80 & $61(76)$ & 1002 & $195(19 \cdot 5)$ \\
\hline
\end{tabular}

* Percentage of litters showing loss in parentheses.

$\uparrow$ Percentage of eggs and embryos lost in parentheses.

Partial loss of litters-overall loss

Of the eighty (Group 3) rats studied throughout pregnancy only nineteen $(24 \%)$ showed no loss of eggs or embryos. The total prenatal losses for these rats are summarized in Table 13 . Less than $20 \%$ of the corpora lutea counted were not represented by viable foetuses at autopsy. Regression analyses revealed no significant correlations between the percentage of litters showing loss, or the percentage of eggs and embryos lost, in relation to the number of eggs ovulated. It can be seen that some prenatal loss occurred in $76 \%$ of all litters.

The data concerning the amount of pre- and post-implantation loss in rats of all groups are summarized in Table 14. Pre-implantation loss in the three different groups of rats varied from 9.8 to $13.9 \%$, but the overall mean percentage loss before implantation only amounted to $11 \cdot 1 \%$. When this figure is combined with the figure of $7.7 \%$ for post-implantation loss, a figure of $18.8 \%$ for overall prenatal loss is obtained. This figure is closely similar to the figure of $19.5 \%$ recorded for the eighty (Group 3) pregnancies shown in Tables 8 and 13. 
It would appear that $5.9 \%$ of the eggs ovulated failed to become fertilized and a further $5.2 \%$ were fertilized but developed only as far as the morula stage. The distribution of post-implantation losses as percentages of the number of implantations have already been presented in Table 10 . However when these losses are recalculated as percentages of the original number of ovulations, it is found that $5.6 \%$ of the embryos were lost in early pregnancy, $1.5 \%$ in middle pregnancy, and only $0.6 \%$ in late pregnancy. Total losses after implantation amounted to $7.7 \%$ of the number of eggs ovulated.

TABLE 14

AMOUNT OF PRE- AND POST-IMPLANTATION AND TOTAL PRENATAL LOSS

\begin{tabular}{c|c|c|c}
\hline \multirow{2}{*}{ Group No. } & \multirow{2}{*}{ Stage } & \multicolumn{2}{|c}{ Eggs or embryos } \\
\cline { 2 - 3 } & & Total & Lost \\
\hline 1 & Before blastocyst & 187 & $26(13 \cdot 9)^{*}$ \\
2 & Before implantation & 918 & $90(9 \cdot 8)$ \\
3 & Before implantation & 856 & $101(11 \cdot 8)$ \\
\hline & Total & 1961 & $217(11 \cdot 1)$ \\
\hline 3 & After implantation & 856 & $66(7 \cdot 7)$ \\
\hline
\end{tabular}

* Percentage of total loss in parentheses.

RESULTS OF THE MEASUREMENTS MADE AT AUTOPSY

The eighty (Group 3) rats were autopsied between Days 18 and 20 of pregnancy, and the foetal and placental weights and foetal lengths were recorded. These data are summarized in relation to day of autopsy in Table 15. It can be seen that foetal weight increases very rapidly while foetal length and placental weight do so much more slowly.

TABLE 15

MEAN FOETAL WEIGHT AND LENGTH AND MEAN PLAGENTAL WEIGHT IN RELATION TO DAY OF PREGNANCY

\begin{tabular}{|c|c|c|c|c|c|c|}
\hline \multicolumn{2}{|c|}{$\begin{array}{l}\text { Day of pregnancy } \\
\text { autopsy performed }\end{array}$} & \multirow{2}{*}{$\begin{array}{c}\text { No. } \\
\text { preg- } \\
\text { nancies }\end{array}$} & \multirow{2}{*}{$\begin{array}{c}\text { No. } \\
\text { foetuses }\end{array}$} & \multicolumn{2}{|c|}{ Foetal } & \multirow{2}{*}{$\begin{array}{c}\text { Placental } \\
\text { Weight }(g) \\
\text { Mean } \pm \text { S.E. }\end{array}$} \\
\hline Day & Time & & & $\begin{array}{l}\text { Weight }(g) \\
\text { Mean } \pm \text { S.E. }\end{array}$ & $\begin{array}{l}\text { Length }(\mathrm{cm}) \\
\text { Mean } \pm \text { S.E. }\end{array}$ & \\
\hline $\begin{array}{l}18 \\
19 \\
19 \\
20\end{array}$ & $\begin{array}{l}2 \text { p.m. to } 5 \text { p.m. } \\
10 \text { a.m. to } 1 \text { p.m. } \\
2 \text { p.m. to } 5 \text { p.m. } \\
10 \text { a.m. to } 1 \text { p.m. }\end{array}$ & $\begin{array}{r}5 \\
46 \\
17 \\
12\end{array}$ & $\begin{array}{r}52 \\
471 \\
170 \\
114\end{array}$ & $\begin{array}{l}0.720 \pm 0.0105 \\
1 \cdot 169 \pm 0.0041 \\
1 \cdot 256 \pm 0.0072 \\
1.794 \pm 0.0098\end{array}$ & $\begin{array}{l}1 \cdot 86 \pm 0.0149 \\
2 \cdot 31 \pm 0.0044 \\
2 \cdot 28 \pm 0.0091 \\
2 \cdot 69 \pm 0.0102\end{array}$ & $\begin{array}{l}0.270 \pm 0.0048 \\
0.347 \pm 0.0018 \\
0.353 \pm 0.0027 \\
0.413 \pm 0.0037\end{array}$ \\
\hline
\end{tabular}

The mean ovarian weight at autopsy was calculated in relation to the number of corpora lutea and these results are set out in Table 16. There was a highly significant $(P<0.001)$ correlation between these two factors. There was no indication that the relationship between ovarian weight and the number of 
corpora lutea was not linear, and from this linear relationship the following data can be calculated: (i) weight of the ovary with no corpora lutea $=21 \cdot 2$ $\mathrm{mg} \pm 1.6$ (s.E.), (ii) weight of a single corpus luteum $=4.56 \mathrm{mg} \pm 0.25$ (s.E.). Thus the regression line can be given by the formula: $y=21 \cdot 2+4 \cdot 56 x$ (where $y=$ mean ovarian weight $(\mathrm{mg})$ and $x=$ number of corpora lutea). The predicted values calculated from this formula are set out in a separate column in Table 16. This close agreement between the predicted and observed values, based on the addition of an estimated weight for a single corpus luteum, indicates fairly conclusively that the mean corpus luteum weight does not decrease even though the total number of corpora lutea present increases.

TABle 16

MEAN OVARIAN WEIGHT IN RELATION TO THE NUMBER OF GORPORA LUTEA ON THE OVARY

\begin{tabular}{c|c|c|c|c|c}
\hline $\begin{array}{c}\text { No. } \\
\text { corpora lutea } \\
(x)\end{array}$ & $\begin{array}{c}\text { No. } \\
\text { ovaries }\end{array}$ & \multicolumn{3}{|c|}{ Ovarian wt. $(\mathrm{mg})$} & $\begin{array}{c}\text { Calculated mean ovarian } \\
\text { wt. }(\mathrm{mg})\end{array}$ \\
\cline { 2 - 3 } & & Total & Mean & Range & $y=21 \cdot 2+4 \cdot 56 x$ \\
\hline 0 & - & - & - & - & $21 \cdot 2$ \\
1 & 1 & 26 & $26 \cdot 0$ & 26 & $25 \cdot 8$ \\
2 & 5 & 148 & $29 \cdot 6$ & 23 to 36 & $30 \cdot 3$ \\
3 & 8 & 288 & $36 \cdot 0$ & 30 to 41 & $34 \cdot 9$ \\
4 & 16 & 622 & $38 \cdot 8$ & 31 to 49 & $39 \cdot 4$ \\
5 & 22 & 942 & $42 \cdot 8$ & 27 to 53 & $44 \cdot 0$ \\
6 & 34 & 1666 & $49 \cdot 0$ & 38 to 65 & $48 \cdot 6$ \\
7 & 34 & 1832 & $53 \cdot 9$ & 44 to 73 & $53 \cdot 1$ \\
8 & 19 & 1091 & $57 \cdot 4$ & 46 to 70 & $57 \cdot 7$ \\
9 & 14 & 870 & $62 \cdot 1$ & 52 to 72 & $62 \cdot 2$ \\
10 & 6 & 392 & $65 \cdot 3$ & 44 to 76 & $66 \cdot 8$ \\
13 & 1 & 79 & $79 \cdot 0$ & 79 & $80 \cdot 5$ \\
\hline Total & 160 & 7956 & $49 \cdot 7$ & 23 to 79 & \\
\hline
\end{tabular}

Eighty Group 3 rats.

\section{DISGUSSION}

Fertility is high in this strain of rats. The mean number of foetuses carried to term is $10 \cdot 1$, a figure considerably higher than those previously recorded in laboratory rats (King \& Stotsenburg, 1915; Slonaker \& Card, 1918; Long \& Evans, 1922; Hanson \& Sholes, 1924; Hain, 1932; Tyler \& Chapman, 1948).

Previous studies in the mouse (MacDowell, Allen \& MacDowell, 1929), the wild rat (Perry, 1945), the bank-vole (Brambell \& Rowlands, 1936) and the wild rabbit (Brambell, 1944; Watson, 1957) have shown that there is a significant relationship between body weight and the number of eggs ovulated. This relationship has been confirmed in the present study for the albino rat. In the mouse (Bowman \& Roberts, 1958) and rabbit (Adams, 1960a) the number of eggs that fail to implant is significantly related to the number of eggs ovulated. This also has been confirmed in the present study. Bowman \& Roberts carried their analysis a stage further, and found that "as the number of eggs shed into the uterine horn increases the probability of each individual egg implanting decreases". They showed that the fertilization rate was not influenced by the 
number of eggs in the Fallopian tube, and therefore considered that the factors causing the variation in the number of eggs implanting must be operating only on the fertilized eggs. However, McLaren \& Michie (1956) found that in their experiments on mice the number of successful implantations rose linearly by increments of 0.225 for each additional egg entering the uterus. Under their conditions there was no evidence of increasing proportional loss of eggs before implantation. Bowman \& Roberts suggested that the discrepancy between their results and those of McLaren \& Michie (1956) may be explained by the fact that the latter workers were transferring eggs that had already reached the blastocyst stage, while in their own material the increased proportionate mortality could have occurred between fertilization and the blastocyst stage.

Adams (1960b, c) has observed that the majority of pre-implantation loss in the rabbit is associated with development from morula to blastocyst. In the present study, while it has not been possible, owing to the small number of observations, to establish a significant correlation between the number of eggs ovulated and the number of eggs failing to develop into blastocysts, it has been observed that $47 \%$ of pre-implantation loss is associated with failure of development at or before this stage. The remaining pre-implantation mortality appeared to be associated with failure of fertilization.

Owing to the fact that in only a small number of pregnancies was it possible to assess which eggs had failed to become fertilized, further analyses of the factors influencing pre-implantation loss were of necessity carried out on the total number of eggs lost before implantation. It was, however, shown that loss of eggs before implantation was proportionately increased when a large number of eggs was shed from a single ovary. Since the number of eggs shed by one ovary failed to influence the number of eggs lost in the opposite uterine horn it was assumed that pre-implantation loss was not caused by any systemic effect but was local to each uterine horn, and was dependent on the number of eggs entering that horn. Adams (1962) has postulated that the normal supply of uterine nutrients is insufficient to meet requirements of abnormal numbers of morulae developing into blastocysts in one uterine horn. Whether the transition from morula to blastocyst is quite so critical in the mouse as in the rabbit (Adams, 1958) is open to doubt, since mouse eggs have been cultured to the blastocyst stage in vitro and have produced live young when retransferred to recipient mice (McLaren \& Biggers, 1958), but no rat eggs have so far been cultured to the blastocyst stage in vitro (Austin, 1961).

McLaren \& Michie (1959) and Fowler \& Edwards (1960) found that progesterone injections did not reduce prenatal loss in superovulated mice. Adams (1962) observed in rabbits that where the number of embryos was much greater than the number of corpora lutea embryonic survival was not affected by the smaller production of endogenous progesterone. Conversely Moore, Rowson \& Short (1960) have shown that the use of superovulated recipients, in which the number of corpora lutea was greater than the number of eggs transferred and the progesterone levels correspondingly higher than normal, did not increase egg survival in the sheep. In the present study it was found that no matter how many corpora lutea were present on the ovary their mean weight remained constant. If weight is related to secretory function, this finding might indicate 
that total progesterone secretion increased as the number of corpora lutea increased, and that the average amount of progesterone secreted by a single corpus luteum did not decrease as the number of corpora lutea on the ovary increased. If this is the case, then progesterone deficiency is unlikely to be a factor contributing to pre-implantation loss.

It has been shown that at the time of transition from the morula to the blastocyst stage, oxygen consumption by the developing egg increases greatly both in the rat (Sugawara \& Umezu, 1961) and rabbit (Fridhandler, Hafez \& Pincus, 1957; Fridhandler, 1961). Suguwara \& Umezu (1961) found that the same value for oxygen consumption by rat eggs cultured in whole serum can only be obtained in artificial media composed of calcium chloride-free KrebsRinger-phosphate buffer plus either $0 \cdot 1 \%$ glucose or serum $(1: 1)$. LutwakMann (1960) reported that the glucose content of rabbit blastocysts increases from 8 to $17 \mathrm{mg} / 100 \mathrm{ml}$ on Day 6 post coitum to 45 to $80 \mathrm{mg} / 100 \mathrm{ml}$ on Day 7 post coitum. Fridhandler (1961) postulated that in the pre-blastocyst rabbit egg glucose is oxidized mainly via the hexose monophosphate oxidation pathway, but that after blastocyst formation its oxidation occurs mainly by the EmbdenMeyerhof pathway and the tricarboxylic acid cycle. Thus the change of the pathway of glucose metabolism in the egg is intimately concerned with its development into a blastocyst. It is possible that the amount of glucose or other nutrient substrates available for uptake by the morula may affect its development into a blastocyst. Thus the haemodynamic effect (McLaren \& Michie, 1960), which is discussed more fully below, may influence loss not only during middle and late pregnancy, but also during this critical stage of development.

In the present study, $7 \cdot 1 \%$ of the rats mated failed to become pregnant. Adams (1960c) recorded that in 5\% of pregnancies in rabbits all the eggs were lost before implantation. In contrast, Frazer (1955) found that in his strain of rats $55 \%$ failed to become pregnant after mating. Edwards \& Fowler (1959) observed that $6 \%$ and $12 \%$ of control mice of two strains suffered total loss before implantation. Bowman \& Roberts (1958), who killed forty-one mice on Day 1 of pregnancy and recovered the eggs from the Fallopian tubes, found that $12.6 \%$ of the eggs were not fertilized. However, it is likely that they included in this calculation mice with all their eggs unfertilized. In another sixty-six mice total pre-implantation loss only amounted to $15 \cdot 5 \%$, so it would seem that under their conditions the major part of this loss was associated with failure of fertilization.

Tyler \& Chapman (1948) recorded that pre-implantation loss amounted to $11.8 \%$ in forty control rats in their first pregnancy. This was lower than the figures for groups of similar rats in their second, third, fourth or fifth and subsequent pregnancies. For 118 rats of all pregnancy groups combined a mean of $14.1 \%$ of eggs were lost before implantation. In the 145 pregnancies studied in the present experiments, only $10.8 \%$ of the eggs were lost before implantation. This figure agrees well with that of Tyler \& Chapman (1948) for the albino rat, and that of Perry (1945) for the wild rat, but not with that of Evans \& Bishop (1923) for the albino rat. In the present experiments post-implantation loss was found to amount to $7 \cdot 7 \%$. Tyler \& Chapman (1948) observed that the loss of embryos after implantation in forty rats during their first pregnancy 
amounted to $5.4 \%$, and for 118 rats of all parities combined was $7 \cdot 3 \%$. Perry (1945) found that $12 \%$ of the embryos in the wild rat were lost between Day 8 of pregnancy and term. Evans \& Bishop (1923) showed that in their strain of rats post-implantation loss amounted to $6.3 \%$. In general, the present figures agree fairly closely with previously recorded estimates of post-implantation loss.

Tyler \& Chapman (1948) recorded that the majority of post-implantation loss in their rats occurred before the $10 \mathrm{~mm}$ crown-rump stage, and that the percentage of resorptions did not increase significantly in the latter part of gestation. Frazer (1955) claimed that in his strain of rats embryonic loss between implantation and Day 10 of pregnancy was very heavy. He observed that $32.9 \%$ of the eggs that implanted were lost before Day 10 , while only $11.4 \%$ of the embryos surviving to Day 10 failed to survive to the end of pregnancy. More detailed analyses of the distribution of post-implantation loss have been carried out by Adams (1960a, 1962) in the rabbit and by Edwards \& Fowler (1959) and McLaren \& Michie (1959) in the mouse. McLaren \& Michie (1959) divided loss of embryos after implantation into three periods-early, middle and late - of pregnancy. They found that most post-implantation mortality occurred during early and middle pregnancy, and in almost all their experimental groups greater losses were observed during the early period. Edwards \& Fowler (1959) recorded that in superovulated mice the greatest loss occurred at parturition, but that the next greatest period of loss occurred between implantation and Day $11 \frac{1}{2}$ of pregnancy. In the present study, the greatest loss of embryos occurred before Day 11 of pregnancy, although a proportion were also lost between Days 11 and 13. Practically no foetuses were lost after Day 13. No correlation between loss of embryos during early pregnancy and the number present in the uterine horn was found in the mouse (Bowman \& Roberts, 1958; Edwards \& Fowler, 1959; McLaren \& Michie, 1959), or in the rat (present study). Adams (1962), however, showed that in the rabbit by artificially increasing the numbers implanting in a uterine horn by egg transfer the percentage of embryos dying during the early period increased proportionately with uterine overcrowding.

Edwards \& Fowler (1959) and McLaren \& Michie (1959) in the mouse, and Adams (1962) in the rabbit all observed that embryonic deaths during middle and late pregnancy are related to the number of embryos surviving into the middle period in a single uterine horn. In other words, uterine overcrowding plays a large part in determining the amount of loss during the middle and late periods of pregnancy. In the present study insufficient embryos and foetuses died during middle and late pregnancy for any such correlation to be significant.

McLaren \& Michie (1960) suggested that the mechanism whereby crowding determines how many embryos will survive to term can be explained by the haemodynamic theory propounded by Eckstein, McKeown \& Record (1955). These authors postulated that since resistance to blood flow through the placenta is low, the pressure at which it is supplied to each placenta may be inversely related to the number of placenta supplied by the uterine artery on the same side. Healy, McLaren \& Michie (1960) and McLaren \& Michie (1960) extended this concept and concluded that it seemed to "account well enough for variations in foetal growth other than those due to genetic differences 
between pregnant females". Adams's (1962) observations on prenatal mortality in the rabbit confirm the applicability of this theory to post-implantation loss in this species.

In the strain of rats under discussion in this paper, it appears that the numbers of embryos that develop in any one uterine horn are not large enough to reduce the blood flow to each placenta in the horn sufficiently to cause substantial middle and late deaths. In one rat twelve eggs implanted in one uterine horn and ten embryos were carried to the end of pregnancy, while in another ten eggs implanted and none were lost (see Table 10). These were the largest numbers of foetuses carried to the end of pregnancy in one uterine horn.

\section{TABLE 17}

A COMPARISON OF THE MEAN DIAMETERS (MM) OF NORMAL IMPLANTATION SiTES IN RELATION TO THE DAY OF PREGNANCY, OBTAINED BY DIFFERENT WORKERS

\begin{tabular}{|c|c|c|c|c|c|c|c|}
\hline \multirow{3}{*}{$\begin{array}{c}\text { Day of } \\
\text { pregnancy }\end{array}$} & \multicolumn{2}{|c|}{ Williams (1948) } & \multicolumn{2}{|c|}{ Tyler $\mathcal{E}^{2}$ Chapman (1948) } & \multicolumn{3}{|c|}{ Present study } \\
\hline & \multirow{2}{*}{$\begin{array}{l}\text { No. } \\
\text { rats }\end{array}$} & \multirow{2}{*}{$\begin{array}{c}\text { Diameter of sites } \\
(\text { mean })\end{array}$} & \multirow{2}{*}{$\begin{array}{l}\text { No. } \\
\text { sites }\end{array}$} & \multirow{2}{*}{$\underset{(\text { mean })}{\text { Diameter of sites }}$} & \multirow{2}{*}{$\begin{array}{l}\text { No. } \\
\text { sites }\end{array}$} & \multicolumn{2}{|c|}{ Diameter of sites } \\
\hline & & & & & & Mean & Range \\
\hline 7 & 1 & $2 \cdot 48$ & - & - & 47 & $2 \cdot 41$ & 2.0 to 2.8 \\
\hline 8 & 2 & 3.00 & - & - & 52 & $2 \cdot 85$ & $2 \cdot 4$ to $3 \cdot 4$ \\
\hline 9 & 1 & $3 \cdot 20$ & _- & - & 56 & 3.23 & 2.9 to 3.5 \\
\hline 10 & 1 & 3.22 & - & - & 62 & 3.77 & 3.3 to 4.8 \\
\hline 11 & 1 & 3.68 & - & - & 66 & $4 \cdot 37$ & $3 \cdot 7$ to $5 \cdot 0$ \\
\hline 12 & - & - & 4 & 5.75 & 57 & $5 \cdot 26$ & 4.3 to 5.9 \\
\hline 13 & 1 & $7 \cdot 50$ & 5 & $7 \cdot 50$ & 48 & 6.94 & 6.2 to 7.8 \\
\hline 14 & - & - & 6 & $8 \cdot 80$ & 61 & $8 \cdot 04$ & 7.2 to 8.7 \\
\hline 15 & 1 & $8 \cdot 50$ & 14 & $9 \cdot 80$ & 59 & 9.07 & 8.2 to 10.4 \\
\hline 16 & - & - & 16 & $11 \cdot 50$ & 52 & $10 \cdot 26$ & 9.6 to 10.9 \\
\hline 17 & - & - & 5 & $13 \cdot 20$ & - & - & $-\quad-$ \\
\hline 18 & - & - & 9 & $14 \cdot 60$ & - & - & - \\
\hline 19 & - & - & 8 & $14 \cdot 10$ & - & - & - \\
\hline
\end{tabular}

It was noticeable that no deaths occurred during middle pregnancy until at least five or more eggs had implanted in one uterine horn (see Table 10), and the loss of embryos during the middle and late periods was small even when up to nine embryos were developing in one horn. McLaren \& Michie (1959) recorded that in the mouse where more than eight foetuses were present in a horn mortality was increased, and Adams (1962) found increased late deaths in the rabbit with more than seven young in a horn.

The distribution of embryonic loss in the rat, related to early, middle and late pregnancy on the basis of autopsy findings, was found to be closely correlated with an assessment of the viability of a site by considering its diameter in relation to stage of pregnancy (see Text-fig. 4). Previous measurements of the diameters of the implantation sites in the rat uterus have been made by Tyler \& Chapman (1948) and Williams (1948). Their results are compared with those obtained in the present study in Table 17. It can be seen that the results are in close agreement. In those cases where some discrepancy occurs, it is noteworthy that the results recorded by the earlier authors, using fewer animals, nearly always fall 
within the limits of the range of diameters observed in this study for the same day of pregnancy.

It would appear that after Day 13 of pregnancy measurement of the diameter of the implantation site can in general give a good indication of the viability of the associated foetus. Under special circumstances measurements made at earlier times may also be used to assess the viability of the embryos. When the mean diameters of the implantation sites that regress during early pregnancy (moles) or during middle pregnancy (atrophic placentae) are calculated, it is found that they start to diverge significantly from the mean diameter of the normal sites one day after the last probable date of their failure to survive. During the next $24 \mathrm{hr}$ these sites grow more slowly until they reach their greatest mean diameter, and then start to regress. Huggett \& Pritchard (1945) observed that by the 12th day rat embryos that had died spontaneously were already resorbing. They suggested that the significance of the 11 th to 12 th days lay in the changeover in type of placentation from yolk-sac to allantoic placenta. They also noted that by whatever method foetal death was produced, the placenta tended to survive and grow more or less normally, particularly if the allantoic mesoderm was present.

This may account for the continued slow growth of those sites observed in the present study which were subsequently found to have regressed. Adams (1960d) found that, if rabbit embryos are killed before Day 15 of pregnancy, only atrophic placentae are found at autopsy; resorption of the dead embryos is very rapid, and is completed within 2 days. He also (1960a) measured the diameters of implantation sites in rabbits and observed good correlation with their ultimate fate.

Total prenatal loss in this strain of rats only amounted to $18.8 \%$, a figure which compares well with that of $20.5 \%$ recorded by Perry (1945) for the wild rat and that of $17.2 \%$ found by Tyler \& Chapman (1948) in the albino rat. Frazer (1955) observed that in his strain of rats post-implantation loss alone amounted to $44.3 \%$. Since prenatal loss in this high fertility strain is no lower than that observed by other workers for strains of rats with much lower mean litter sizes, its greater fertility must depend upon a larger number of eggs being shed at each ovulation. The mean number of eggs shed by 145 virgin rats was found to be $12 \cdot 2 \pm 0 \cdot 19$, a figure which is high for a placental mammal. In the mouse, McLaren (1962) suggested that the principal effect of selection for an increase in the number of eggs shed at each oestrus has been to increase the sensitivity of the ovary to follicle-stimulating hormone.

In $55 \%$ of litters some eggs were lost before implantation, and $55 \%$ of litters showed some loss of embryos after implantation, but only $76 \%$ of all litters experienced some loss throughout pregnancy. Tyler \& Chapman (1948) observed that $52.5 \%$ of rats suffered loss of embryos after implantation. In the wild rat Perry (1945) noted that prenatal loss only occurred in $56.7 \%$ of all litters, but he suspected that in some litters all the embryos were lost after implantation. Adams (1960a) found that $53.3 \%$ of domestic rabbits suffered some pre-implantation loss, and $70.8 \%$ some post-implantation loss. In $3.3 \%$ of pregnancies total loss occurred after implantation. In the wild rabbit not less than $35 \%$ of litters suffered complete loss after implantation (Brambell \& Mills, 
1948). By comparison, Watson (1957) noted that the whole litter was lost in only $18 \%$ of wild rabbits in New Zealand. Edwards \& Fowler (1959) reported that all the embryos were lost after implantation in $3 \%$ of pregnant control mice. In the present experiments no rat lost all its embryos after implantation.

\section{ACKNOWLEDGMENTS}

I am indebted to Mr B. P. Welford for performing many of the statistical analyses and for statistical advice, and I am also grateful to Mrs A. Smith for technical assistance. I would also like to thank Dr A. L. Walpole and Dr C. E. Adams for reading and discussing this manuscript.

\section{REFERENCES}

Adams, C. E. (1958) Egg development in the rabbit: the influence of post-coital ligation of the uterine tube and of ovariectomy. F. Endocrin. 16, 283.

Adams, C. E. (1960a) Prenatal mortality in the rabbit, Oryctolagus cuniculus. F. Reprod. Fertil. 1, 36.

ADAms, C. E. (1960b) Studies on prenatal mortality in the rabbit Oryctolagus cuniculus: the amount and distribution of loss before and after implantation. F. Endocrin. 19, 325.

Adams, C. E. (1960c) Early embryonic mortality in the rabbit. F. Reprod. Fertil. 1, 315.

Adams, C. E. (1960d) Embryonic mortality induced experimentally in the rabbit. Nature, Lond. 188, 332.

Adams, G. E. (1962) Studies on prenatal mortality in the rabbit, Oryctolagus cuniculus: the effect of transferring varying numbers of eggs. 7 . Endocrin. 24, 471.

Austiv, G. R. (1961) The mammalian egg, p. 183. Blackwell Scientific Publications, Oxford.

Bouricius, J. K. (1948) Embryological and cytological studies in rats heterozygous for a probable reciprocal translocation. Genetics, 33, 577 .

Bowman, J. C. \& Roberts, R. C. (1958) Embryonic mortality in relation to ovulation rate in the house mouse. F. exp. Biol. 35, 138.

Brambell, F. W. R. (1944) The reproduction of the wild rabbit, Oryctolagus cuniculus (L.). Proc. zool. Soc. Lond. 114, 1.

Brambell, F. W. R. \& Mil.s, I. H. (1948) Studies on sterility and prenatal mortality in wild rabbits. IV. The loss of embryos after implantation. $\mathcal{7}$. exp. Biol. 25, 241.

Brambell, F. W. R. \& Rowlands, I. W. (1936) Reproduction of the bank vole (Evotomys glareolus Schreber). I. The oestrous cycle of the female. Phil. Trans. B, 226, 71.

Eckstein, P., McKeown, T. \& Record, R. G. (1955) Variation in placental weight according to litter size in the guinea-pig. 7. Endocrin. 12, 108.

Edwards, R. G. \& FowLER, R. E. (1959) Fetal mortality in adult mice after super-ovulation with gonadotrophins. F. exp. Zool. $41,299$.

Evans, H. M. \& Bishop, K. S. (1923) On the relation between fertility and nutrition. III. The normal reproductive performance of the rat. 7. metab. Res. 3, 201.

Feldman, H. W. (1926). Contributions to a knowledge of inheritance in mammals. II. Fertility and sterility in the Norway rat, Mus norvegicus. Publ. Carneg. Instn. No. 337, p. 49.

Fisher, R. A. \& YAtes, F. (1957) Statistical tables for biological, agricultural and medical research, 5th edn. Oliver \& Boyd, Edinburgh.

Fowler, R. E. \& EDWARDs, R. G. (1960) Effect of progesterone and oestrogen on pregnancy and embryonic mortality in adult mice following superovulation treatment. $\mathcal{F}$. Endocrin. 20, 1.

Frazer. J. F. D. (1955) Foetal death in the rat. F. Embryol. exp. Morph. 3, 13.

Fridhander, L. (1961) Pathways of glucose metabolism in fertilized rabbit ova at various preimplantation stages. Exp. Cell Res. 22, 303.

Fridhandler, L., Hafez, E. S. E. \& Pincus, G. (1957) Developmental changes in the respiratory activity of rabbit ova. Exp. Cell Res. 13, 132.

HaIN. A. M. (1932) Increase in weight of the mother and of the foetus during pregnancy (rat). Quart. F. exp. Physiol. 22, 71 .

Hanson. F. B. \& Sholes, F. N. (1924) Seasonal differences in sex ratio, litter size and birth weight of the albino rat under uniform laboratory conditions. Genetics, 9, 363.

Healy, M. J. R., McLaren, A. \& Michie, D. (1960) Foetal growth in the mouse. Proc. roy. Soc. B, $153,367$. 
Huggetr, A. St. G. \& Pritchard, J. J. (1945) Experimental foetal death: the surviving placenta. Proc. roy. Soc. Med. 38, 261.

King, H. D. \& Stotsenburg, J. M. (1915) On the normal sex ratio and size of the litter in the albino rat (Mus norvegicus albinus). Anat. Rec. 9, 403.

Long, J. A. \& Evans, H. M. (1922) The oestrous cycle in the rat and its associated phenomena. Mem. Univ. Calif. 6, 1.

Lutwak-ManN, C. (1960) Some properties of early embryonic fluids in the rabbit. F. Reprod. Fertil. 1, 316.

MacDowell, E. G., Allen, E. \& MacDowell, C. G. (1929) The relation of parity, age and body weight to the number of corpora lutea in mice. Anat. Rec. 41, 267.

McLaren, A. (1962) The relation between natural fecundity and response to follicle-stimulating hormone. F. Endocrin. 25, 137.

McLaren, A. \& Biggers, J. D. (1958) Successful development and birth of mice cultivated in vitro as early embryos. Nature, Lond. 182, 877.

MaLAREN, A. \& Michie, D. (1956) Studies on the transfer of fertilized mouse eggs to uterine fostermothers. I. Factors affecting the implantation and survival of native and transferred eggs. 7. $\exp$. Biol. 33, 394.

MaLAREN, A. \& Michie, D. (1959) Superpregnancy in the mouse. I. Implantation and foetal mortality after induced superovulation in females of various ages. 7. exp. Biol. 36, 281.

McLaren, A. \& Michie, D. (1960) Control of pre-natal growth in mammals. Nature, Lond. 187, 363.

MiLler, N. (1911) Reproduction in the brown rat (Mus norvegicus). Amer. Nat. 45, 623.

Moore, N. W., Rowson, L. E. A. \& Short, R. V. (1960) Egg transfer in sheep. Factors affecting the survival and development of transferred eggs. $\mathcal{J}$. Reprod. Fertil. 1, 332.

Perry, J. S. (1945) The reproduction of the wild brown rat (Rattus norvegicus Erxleben). Proc. zool. Soc. Lond. 115, 19.

Slonaker, J. R. \& GARD, T. A. (1918) The effect of omnivorous and vegetarian diets on reproduction in the albino rat. Science, $47,223$.

Sugawara, S. \& Umezu, M. (1961) Studies on the metabolism of the mammalian ova. II. Oxygen consumption of the cleaved ova of the rat. Tohoku 7. agric. Res. 12, 17.

Tyler, W. J. \& Chapman, A. B. (1948) Genetically reduced prolificacy in rats. Genetics, 33, 563.

Warson, J. S. (1957) Reproduction of the wild rabbit, Oryctolagus cuniculus (L), in Hawke's Bay, New Zealand. N.Z. J. Sci. Tech. B, 38, 451.

Williams, M. F. (1948) The vascular architecture of the rat uterus as influenced by estrogen and progesterone. Amer. F. Anat. 83, 247. 